\title{
MUTUAL CONNECTION OF PROFESSIONAL CULTURE CRITERIONS AND REQUIREMENTS OF PROFESSIONAL ETHICS
}

\author{
Ernazarova Yorkinoy Ollaberganovna, \\ National University of Uzbekistan, researcher. \\ E-mail: yo_o_e_2211@mail.ru
}

\section{doi http://dx.doi.org/10.26739/2573-5616-2018-3-2-6}

\begin{abstract}
: this article analyzes philosophical perspectives on the interconnection of professional culture and professional ethics requirements.

Key words: person, profession, professional culture, professional ethics, professional culture criteria, ethical education, ethical culture.
\end{abstract}

Drofessional ethics are clearly visible in the system of disciplinary culture. The reason of this is that any individual, who reaches any profession during his lifetime, has to communicate with others while working. Such relationships can occur among co-workers and colleagues, on the other hand, one can also contact with people who are not working with him together, but just belong to the same profession. Nowadays professional discipline is one of the perfect forms of the disci plinary culture; its place in social disciplinary life is estimated highly.

In the XXI century, several factors such as origination of new professions, influence of modern technologies to the professional activities, process of globalization increase interest in professional ethics. Doctor, pedagogue, lawyer and other practical disci plinary subjects were united with another modern professions such as broker, manager, businessman, programmer, dealer, cosmetologist and et cetera. These professions got their own codecs, defining disciplinary culture criterions.

Discipline of the profession is an important part of disciplinary culture, it unites common culture specifications of the society and professional definitions of duty, shyness, value and others and reflects all of these concepts in the working process of people. Professional discipline evolves with hard work and productiveness and works in the way of prosperity of profession, getting its targets successfully, unification of professional and social interests and supplies transferring social disciplinary positive aspects to the working process. 
Professional culture and professional discipline's common problems are mutually connected to each other. Any professional culture is based on professional disci pline.Professional disci pline consists from such criterions as goodness, duty, honesty, authenticity, humanism and others.Discipline defines rules, that say how person should behave in society, contact with people around, organize spare time and how to look appropriately.

Philosopher Abdulla Sher has his own definition of discipline, and says, "Discipline is able to create positive reputation for aperson, but it is not powerful enough to change people's lives and usually based on national traditions and consists number of beautiful, positive activities and gestures" [1]. So, although discipline belongs to everybody, professional discipline is not for all, but only for those, who live and work in the frames of exact profession. That is why defining "professional discipline" one should understand system of cultural regulations, which control professional relations of people.

Ethics and science of discipline has its own "inner"targets which are considered as essential today. Especially, creating objective history of national-continental disciplinary conscious and restoration of disciplinary values restricted by former Soviet Union are most important goals. These days such problems as solvation of actual questions of theoretical discipline, systematization of disciplinary concepts developing of theoretical sides of disci plinary culture and more than all above, creating modern theoretical basis of professional ethics are waiting their order to be solved.

Professional ethics bring to the life disciplinary norms, principles and qualities of any profession.

Theory of disciplinary upbringing teaches and investigates ways of integrating discipline into regular life according to society's demands, necessities and interests.

There is no absolute, unchangeable, endless discipline in the society. Discipline is a historically flexible concept which has comparative independence.

After some years passed, production of goods, science and technologies will develop and segmentation of social workplaces will deepen. Infinite repetition of this process will take us to creation of types of social activities with their own functions in society. Their owners will complete certain duties, related to their activity. These duties found themselves in the complex of disciplinary rules and norms of behavior.Thus, origination of professional discipline owes its creation to the division of working resources and started playing role of its disciplinary program and disciplinary rating.

Due to this rating we can separate any professional discipline according to its roles and goals in the society to following categories:

- According to specialization of teacher - discipline of pedagogue; 
- According to specialization of medicine - discipline of doctor;

- According to specialization of jurisprudence - discipline of lawyer

- According to specialization of service spheres - ethics of serving and et cetera.

It should be noticed that professional discipline is abigger concept that professional breeding. Professional breeding is developed inside of professional discipline. While professional breeding is based on person's character, professional discipline stands on common norms of human disci plinary borders. Besides professional discipline works as aframework for person's professional duties and defines his attitude towards his profession and unites people according their relation to this or that profession.

Professional ethical requirements cover specific activities for each profession. It is the means of educating each employee to maintain the moral qualities that will help shape the professional duty and ensure that his or her work is performed correctly and accurately.It explores the relationships in labor collectives, as well as the peculiarities of this profession-specific spirituality, and regulates the spiritual relationships of the people in the labor. Moreover, it reflects the ethical standards set out in the relationships among professional ethics, and sets out the ethical requirements for the profession to be based on the socio-cultural nature of one or another profession.

Due to professional ethics, general ethical guidelines are specialized in order to have more impact, and become stronger. In other words, every form of professional ethics has relative independence. Therefore, it is not permitted to abolish its general principles and morals in the matter of morality, to exaggerate the peculiarities of professional behavior: it is appropriate to look at the subject with dialectic integrity.

This process can be noticed in results of forming an entrepreneurial entity and its ethical-aesthetic culture of businessman whose profession emerged in the process of building a legal democratic state based on market relations and the foundations of civil society, and developing the new professional ethics code.

A business entrepreneur, along with certain investments, is a person with profound knowledge of economic knowledge, good experience, initiative and will in his field. It is manifested in the spheres of business production, service, exchange, trade, consumption, etc. In addition to fulfilling its interests, the entrepreneur will meet the needs of people, increase the national wealth, provide people with jobs, enrich the budget through taxation, invest in areas such as culture, education, healthcare, introduce new technologies into production, creates goods and services. 
It is impossible to imagine an entrepreneurial activity out of morality. Generally, the culture of entrepreneurial life requires brilliance, generosity andkindness. The proverbs of the Uzbek people, as well as the spiritual heritage of our ancestors, have been written about it. In this sense, we can say that entrepreneurial and smart people have long been recognized and respected by the nation. It is based on Amir Temur's words, "A man of good courage and boldness, a firm, entrepreneurial and alert person is better than thousands without intercourse" [2].

Objective factors that influence or control the activities of an entrepreneurial entity and regulate this activity are enhanced by the level of ethical culture. After all, an entrepreneur with a high ethical culture does not give up humanistic qualities in order to find a wealth or lose himself in the face of any crisis, and does not make a mistake. Therefore, in any society that chooses to build a market-based, democratic society, the ethical foundations of entrepreneurial activities, the scientifically strengthening, the practical aspects of business, and the development of business ethics are transformed into a social need. This process requires the continuous rationality of the entrepreneur to reflect on personal goals and methods of achieving them [3]. The entrepreneur should be intelligent, enlightened, cultured, and have the highest ethical qualities, always working in the spirit of creativity [4]. This, in turn, demonstrates that ethics is an important criterion for shaping entrepreneurial and entrepreneurial culture. Also, the main goal of the announcement of the year 2018 as the "Year of Support for Innovative Ideas and Innovative Ideas in the Republic of Uzbekistan" [5] is an innovative way of creating an entrepreneurial business, which is based on modern approaches, advanced technology and management methods. The development of this sector is based on the creation of new competitive jobs and, most importantly, creating new jobs and shaping entrepreneurship and entrepreneurial people, who feed themselves and their families, and benefit the entire society, and that there is a need to maintain a coherent professional and ethical culture. In order to extend the range of such entrepreneurs, to create the best conditions for importing and introducing high technologies, techniques and equipment based on the latest achievements of science, to gain experience in leading foreign companies and organizations, and to promote mutually beneficial cooperation high professionalism and the rule of ethics. Indeed, in the market economy, the objective factors that influence or define the activities of a commercial or entrepreneurial entity, and to regulate this process, are determined by the level of ethical culture.

The ethical culture of a person is also characterized by his professionalism and business qualities. The most important of these are initiative, creativity, 
freedom, solidarity, organizationalism, competence, attentiveness, excellence, honesty, and discipline. These qualities are required in all specialties.

The rules of professional ethics are formed in the work, not in the cabinet, and can not be distinguished from creativity in work. However, there are cases when some agencies and their executives are deprived of real-life and public needs. Especially at the moment, it is time for leaders to focus on complex problems, without leaving the cabinet, with deep learning, and focusing on the weaknesses and their roots, without focusing on the "winning reports". Relationships, communication, and behavior that arise in the course of employment can lead to professional ethics. Because each profession has its own peculiarities, and the ethical relationship that exists between people in the process of work is set to some extent based on that attribute. The ethical environment in the team, that is, the values and principles that govern people's behavior and relationships play aspecial role in composing the moral position and needs of a person.

It is also important that a person has a sense of community ethics. This factor, first of all, forms the attitude towards social work and its participants; and secondly, in the process of professional activity, it creates a moral relationship that arises from the collision of professional groups with each other and society.

In this process, the relationship between each staff and the team, the spiritual qualities and attributes of the specialist, the professional relationships and vocational training are important.

Professional ethics is characterized by the strict ethical requirements of certain types of professional activities, not the result of the inequality of professional ethics of different professional groups. This is the field of activity where the labor process requires identifying and defining the actions of each participant.

In Ethics dictionaries, the term "occupational etiquette" is "code of conduct that educates people about their professional activities," [6] and "profession ethics is a science domain that explores the occurrence of morality in various fields, interconnected with and conditioned by the professional activities of a particular social group"[7]. As described above. In this sense, professional ethics can be considered as the moral sum of the relationships that arise from the professional work of people.

Today, the vocational training of the students, according to the opportunities and needs of the youth, is being improved and new methods and forms are being created. In particular, the audience of vocational specializations, based on the general knowledge of education, is expanding. This can only be evident in the field of journalism that the activities of media professionals are gaining momentum. 
One of the peculiarities of professional etiquette is its modernity, which is evidenced by the success of everyday achievements in personal activity. A person can acquire modern knowledge if he adapts to the most advanced concepts of his time. The 21st Century, as well as the intellectual potential, the age of thought and spirituality, creates new challenges for mankind as well.

No one can deny that globalization processes in the world today have created enormous opportunities for the development of all humanity, especially for young people. First of all, the advanced achievements of science and technology, modern information and communication technologies, in particular, the Internet, "distorted" borders between different countries and regions. Now, services related to the life of a person require moral qualities. Particularly, this has become a prerequisite for health and education. The nature of these areas is not only characteristic, but also of a professional duty. The employment of these professionals is not necessarily dependent on service rules and time. It requires creativity according to its content. The complexity of this professional group is determined by the link between "human - object" and "human - subject". Ethical responsibility is crucial.

In this sense, the profession of ethics is aset of ethical principles that defines the relationship of aperson's professional responsibilities to his or her profession, and unites people according to their profession. Although the professional ethics are based on the nature of each profession, they apply to general norms. Because general standards of behavior are the issues of upbringing of spiritual qualities, which will assist the formation of professional duty of each worker, ensuring the correct and accurate performance of his / her duties.

Today, modern technology also requires not only the acquisition, but also the culture of use. After all, the achievement is for personal gain, and someone uses it as a weapon for the pursuit of destructive intentions. Personality's professionalism is determined by the fact that he knows the last achievements of his profession and sets an example for others. In order to be a good example for others, it is important not only to be a professional, but also to combine professional and ethical culture.

At present, there are great opportunities to improve professional skills and to shape professional ethics. For example, the availability of courses aimed at improving the qualifications of different professions (good taste, discretion, discipline, experience, qualifications, knowledge, etc.), the availability of advanced courses in modern technology, advanced training in developed countries, spiritual and moral upbringing and effective forms and methods of educational work, education and training, certification of educational institutions and accreditation and the introduction of an impartial system of quality assurance is a proof of our opinion. 
At present, the formation of the perfect system of personnel training based on the rich intellectual heritage of the people and the achievements of universal values and modern culture, economy, science, and technologyis defined as the most important condition of Uzbekistan's development.

At the same time, in the minds and in the lives of people, new approaches to labor, property, and professions are forming, these approaches do not arise without the influence of ethical culture. The level of moral elevation in the society is defined by the moral culture of citizens. In this context, the following factors that negatively affect the harmonization of professional and ethical culture are contrary to professional ethics and ethical culture: abandon the old; preserve the current situation; indifferent attitude to profession; do not understand the requirements of time; do not end the ongoing work; irresponsibility; formalism; selfishness; covetousness; corruption; slowdowns. Today, the state and society building is linked to the activities of managers in many ways to ensure a decent standard of living and quality. "Critical analysis, strict discipline and personal responsibility are the responsibility of each leader - whether the Prime Minister or his deputy, they should be the daily rule of the work" [8].

Living as an adult and highly qualified worker is a basic criterion for determining the spiritual well-being of the person. One such criterion is responsibility and is widely used as a philosophical category. Responsibility the manifestation of public control, which implies the implementation of various administrative standards of social administration, is legally binding.

Responsibility is a form of social control and self-control over personality behaviors, the professional, personal and business qualities of each person, the way they work, the character of the work, motivation and efficiency of the work and the status of a person and the role and role of a person in the state and society. Responsibility for modern human resource activities is seen as an internal mechanism. It is understood by sense of duty, universal, national and professional standards and values and reflects consciousness in the activity.

The work of the teacher differs from that of the engineer. His work product is determined by the student's morals, knowledge level and aesthetic tone. What are the constituent elements of the ethical culture of the teacher?

It is important to emphasize that the moral culture of the teacher is reflected in personality attributes, beliefs and values, speech culture, gestures, hand movements, aesthetic influence on a speaker, selfdirectedness, and creativity. In this regard, the criteria for the formation of ethical and professional culture in a teacher can be summarized as follows:

a) Creativity. This routine research is a feature of finding a new method, forms, and readiness to share experiences with colleagues; 
b) Communicative. This makes it easier for readers to engage in dialogue, to build a sense of commitment to news, and to help develop interparliamentary relationships;

s) Communitieship. The humanization of this communication process and its observance of professional morality under democratic principles, the dignity of each student as a person are determined by attraction of young people to the high culture of dialogue, empathy, emotional uplift, and aesthetic perception. Teacher should be a moral and aesthetic ideal for the reader, not the broader and deeper educator. The student learns from him a lot.

Each profession has its own unique features. Today, not only the profession but also the rules of professionalism and culture of enterprises and organizations, is indicative of their professional ethics. Avoiding corruption in these enterprises is important in establishing an ethical and aesthetic environment in the community. All staff members have a number of ethical codes that help them improve the moral and ethical environment:

a) Discipline and Respect;

b) Datareceipt and accurate delivery;

c) To act within the limits of his / her competence and duty;

g) To study and teach the experience;

d) Goodness to the team.

The requirements for professional ethics of all employees can also be divided into several areas. Including:

a) the level of knowledge and professionalism required. This necessitates that staff constantly improve their knowledge and professional skills. At the same time, they should be aware of modern and new methods and new information in meaningful work, as they are constantly working to improve their legislation, to be timely aware of the changes and additions they make and to apply them effectively in practice. high level of skill;

b) ethical requirements. To be consistent, clear, transparent and legitimate under the law, to be clear, disciplined, careful, cautious, honest and sincere in dealing with citizens;

c) requirements for ethical culture of employees. This is to be responsive to their duties, to be in line with internal labor discipline (timely access to work and active participation in public affairs) to each employee individually;

As can be seen from the foregoing, the problem of professional ethics is not a matter of minority ethical issues, as in some scientific views. Studying it in every possible way, studying professional freedom and professional duty is an important part of XXI century ethics. Indeed, professional morals should be regarded as a moral event in a moral and ethical manner. 
The circumstances that arise in the workplace have a strong impact on the formation of professional ethics. Because each profession has its own specific features, the ethical relationship that exists between people in the process of work is set to some extent based on that attribute.

In the process of professionalism and work ethics, the relationship between each staff and the team, moral qualities and attitudes, professional relationships, and vocational training that are important for the professional duty of the specialist are essential.

Professional ethics are characterized by the high ethical requirements of the society, not the result of the inequality of the professional ethics of various professional groups. This is the field of activity where the labor process requires identifying and defining the actions of each participant.

Moral values such as debt, conscience, loyalty, justice, honesty and selflessness are signs of the moral culture of a person, and each professional identifies a spiritual image. The personal qualities of a human being begin with abusinesslike description, such as his attitude towards labor and the level of professional training.

\section{References}

1. Sher A.Science of Discipline.Course book.- Tashkent: "Yangiasravlodi", 2003.Page 10.

2. Wisdoms of Amir Temur. - Tashkent: "Uzbekistan", 2011. 11 page.

3. Alle M. Usage effectiveness and economics. - Moscow: "Mysl", 1998. - P.185.

4.MakeevaV.G.Culture of entrepreneurship.- Moscow: Gardariki, 2002.- P.124.

5. The address of the President of the Republic of Uzbekistan ShavkatMirziyoev to the OliyMajlis. Speech /// www.press-service.uz. - 2017.22.12.

6. Dictionary of ethics. - Moscow: "Politizdat", 1981. - P. 274

7. Husanov B., Khudoyberdieva M., Muhammadjonova L., Haydarova H. Occupational Ethics. Textbook. - Tashkent: "Publisher", 2012, p. 52.

8.Mirziyoev Sh.Critical analysis, strict discipline, personal responsibility - should be the daily rule of every leader's activity. - Tashkent: Uzbekistan, 2017, p. 6. 